\title{
Technologie en economen
}

Citation for published version (APA):

Prakke, F. (1988). Technologie en economen. Van Gorcum. https://doi.org/10.26481/spe.19880602fp

Document status and date:

Published: 02/06/1988

DOI:

10.26481/spe.19880602fp

Document Version:

Publisher's PDF, also known as Version of record

\section{Please check the document version of this publication:}

- A submitted manuscript is the version of the article upon submission and before peer-review. There can be important differences between the submitted version and the official published version of record.

People interested in the research are advised to contact the author for the final version of the publication, or visit the DOI to the publisher's website.

- The final author version and the galley proof are versions of the publication after peer review.

- The final published version features the final layout of the paper including the volume, issue and page numbers.

Link to publication

\footnotetext{
General rights rights.

- You may freely distribute the URL identifying the publication in the public portal. please follow below link for the End User Agreement:

www.umlib.nl/taverne-license

Take down policy

If you believe that this document breaches copyright please contact us at:

repository@maastrichtuniversity.nl

providing details and we will investigate your claim.
}

Copyright and moral rights for the publications made accessible in the public portal are retained by the authors and/or other copyright owners and it is a condition of accessing publications that users recognise and abide by the legal requirements associated with these

- Users may download and print one copy of any publication from the public portal for the purpose of private study or research.

- You may not further distribute the material or use it for any profit-making activity or commercial gain

If the publication is distributed under the terms of Article $25 \mathrm{fa}$ of the Dutch Copyright Act, indicated by the "Taverne" license above, 


\section{TECHNOLOGIE EN ECONOMEN}

\section{Rede}

Uitgesproken bij de aanvaarding van het ambt van buitengewoon hoogleraar in de Economie van de technologische ontwikkeling, aan de Rijksuniversiteit Limburg op 2 juni 1988

door

\section{Frits Prakke}

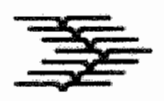

Van Gorcum, Assen/Maastricht 1988 
Alle rechten voorbehouden. Wiels uit deze uitgave mag worden verveelwoudigd, opgeslagen in een geautomatiseerd gegewensbestand, of openbaar gemaakt, in enige vorm of op enige wijze, hetzij electronisch, mechanisch, door fotokopieèn, opnamen, of enig andere manier, zonder voorafgaande schriftelijke toestemming vati de uitgever.

Voor zover het maken van kopieèn uit deze uitgave is toegestaan op grond van artikel $16 \mathrm{~B}$ Autteurswet $1912 \mathrm{j}^{0}$ het Besluit van 20 juni 1974 , St.b. 351 , zoals gewijzigd bij het Besluit wan 23 augustus 1985 , Sit.b. 471 en artikel 17 Auteurswet 1912, dient men de datrwoor wettelijk verschuldigde vergoedingen te voldoen aan de Stichting Reprorecht (Postbus 882, 1180 AW Amstelveen). Voor het overnemen van gedeelte(n) uit deze unitgave in bloemlezingen, readers en andere compilatiewerken (artikel 16 Auteurswet 1912) dient men zich tot de uitgever te wenden.

\section{CIP-GEGEVENS KONINKLUJKE BIBLIOTHEEK, DEN HAAG}

ISBN 9023223802

Deze uitgave is mede tot simand gekomen dankzij een bijur age van het Studiecentrum voor Technologie en Beleid vam TNO te Apeldoorn.

Layout en drak, Wan Gorcum, Assen

[Technological change] represents in essence the mobilization of society's creative energies to relieve the scarcities which existing resources and products cannot" 


\section{TECHNOLOGIE EN ECONOMEN}

\section{NNEIDING}

Wat is het belang van technologie voor economen? Het is een uitdaging om na meer dan 15 jaar vanzelfsprekende praktijk daarvan rekenschap af te moeten leggen voor een gehoor als het uwe. Immers, wat is 'technologie'. Het zou niet zo moeilijk zijn u heel wat langer dan de mij toegestane tijd te vervelen met een minutieuze analyse van vele gangbare definities (zie hierover bijvoorbeeld $\mathrm{E}$.J. Fischer, 1980). Gegeven deze plaats en tijd volsta ik als uitgangspunt met een tweetal anekdotes. De eerste betreft een wereldberoemde hoogleraar aan het Massachusetts Institute of Technology. Hij werd wlak voor zijn emeritaat aangeklampt door een eerstejaars student, wol van dromen over ruimtewaart, kernenergie en automatische fabrieken, die hem vroeg: "Wat is technologie?". De eerbiedwaardige oude man antwoorde: "Technologie is het kunnen maken woor eén dollar van iets dat door iedere idioot voor drie dollar gemaakt kan worden". Economen kunnen tevreden constateren dat technologie wezenlijk te maken heeft met de allocatie van schaarse middelen, maar dan met een belangrijke nadruk op de toepassing van kennis daarbij.

Een tweede anekdote illustreert de grote variatie die mogelijk is in de benadering van de technologie als onderwerp van studie. Het is het verhaal van de ambitieuze maar nog jonge uitgever die een internationaal aansprekende publikatie over de olifant wilde maken. Daartoe gaf hij opdracht aan een Duitse geleerde. Deze leverde hem na een jaar studie en vele dure voorschotten een boek 'Der Elephant' van duizend bladzijden, waarin tot in detail en met zeer veel tabellen, schema's en voetnoten alle bekende feiten over de fysiologie, anatomie, en gedrag van de olifant beschreven waren. Het manuscript ging vergezeld wan een brief waarin de auteur tot zijn spijt betuigde dat hij nog niet gereed was, maar dat de delen II, III en IV nog zouden volgen. Teleurgesteld richtte onze jonge uitgever zijn verzock nu aan een Franse geleerde. Deze produceerde binnen zes maanden een tekst over het liefdesleven van de olifanten, 'papa éléphant', 'maman éléphant', et "les petits bébés éléphants'. Een in fraaie stijl geschreven, wat korte tekst, verluchtigd met fraie tekeningen in roze en grijs. Vertederd maar toch teleurgesteld toog onze uitgever nu naar Amerika waar hij weldra een geleerde bereid vond bimnen drie maanden een boek te schrijwen. Precies op tijd kreeg hij het manuscript: 100 bladzijden, inclusief uitgebreide inhoudsopgave en handige index, thet de titel: "The elephant: how to cut it, cook it and eat it".

Evenals de olifant geeft de technologie aanleiding tot zeer diverse benaderingen. In een reeks wan economische scholen, vanaf Adam Smith met zijn achttiende eeuwse speldenfabriek tot de recente evolutionaire theorieen met hun waterketel (Soete, 1987), wordt technologie steeds op een eigen manier gecon- 
cipieerd. Nog groter wordt de variatie als we aanverwante wetenschapsgebiedlen zoals de organisatiesociologie en bedrijfskunde erbij betrekken. Veel van deze benaderingen zijn woor economen van belang. Het heeft niet veel zin ze in dit verband allemaal in kaart te brengen noch om daaruit een bepaalde keus te maken. Op een wat algemener niveau dan dat van specifieke theoretische kaders wil ik wel twee aspecten van de technologie bespreken die naar mijn persoonlijke overtuiging van bijzonder belang zijn voor economen, in welke subdiscipline of theoretisch kader dan ook, en dus van belang voor deze Faculteit der Economische Wetenschappen in Maastricht. Het eerste is de technologie in de vorm van de woortdurende stroom van technische innowaties, als belangrijk maatschappelijk werschijnsel dat onderwerp moet zijn van gespecialiseerd economisch onderzoek. Het tweede is technologie als metafoor voor verandering in de omgeving van het economische systeem en dus als continue uitdaging aan economen in hun theorie en in hun praktijk.

\section{TECHNOLOGIE ALS SPECIALISATIE VOOR ECONOMEN}

Evenals de landbouw, gezondheidszorg, werkeer en vervoer en regionale ontwikkeling moet technologie in de gedaante van technische innovatie een onderwerp zijn van gespecialiseerd economisch onderzoek. Zowel bij ondernemingen als bij overheid en semi-overheid wordt technologie in toenemende mate als belangrijk ervaren, als probleem ên als uitdaging. In nagenoeg alle westerse industrielanden nemen de uitgaven van onderzoek en ontwikkeling toe. Tegelijkertijd wordt meer dan vroeger van dit soort uitgaven verwacht dat concrete economische resultaten behaald worden. In de zeventiende eeuw nam Lodewijk XIV Christiaan Huygens in dienst omdat deze uitvinder wan het slingeruurwerk een sieraad voor het Franse hof was. Twintig jaar geleden was het nog mogelijk om miljarden guldens te investeren in prestige objecten zoals het supersonische verkeersvliegtuig de Concorde en de kweekreactor in Kalkar zonder een al te kritische analyse van kosten en baten. Tegenwoordig komt het daarentegen voor dat onderzoekvoorstellen voor fundamenteel onderzoek op het gebied van de natuurkunde worden onderworpen aan een analyse van de mogelijke baten voor kleine en middelgrote bedrijven. Een steeds groter deel wan de research uitgaven van grote bedrijven wordt onderworpen aan de financiële controle van produktdivisies. Dit betekent een uitdaging voor economen, die steeds vaker bij dit soort afwegingsprocessen worden betrokken. Erkenning van de eigen inbreng moet verworven worden door een grotere gebiedskennis en door het ontwikkelen van adequate concepten en bruikbare, empirisch getoetste kwantitiatieve indicatoren. We schieten als economen tekort als we alleen robots kunnen tellen terwijl er ontwikkelingen gaande zijn in bet produktieproces die alle bestaande verhoudingen en spelregels op hun kop zetten. Het berekenen van de pay-back periode is niet voldoende als door een investering in 'computer integrated manufacturing, CIM, ingrijpende wijzigingen plaatswinden in de kwaliteit van de produkten, de flexibiliteit van het produktieproces en de kwallficatie-eisen aan de werknemers. De behoefte aan economische analyse bij de besl uitvorming over technische innovatie is groeiende, maar de feitelijke acceptatie van de econoom als deskundige naast de technologie is vaak nog gering. 
De toename in uitgaven voor onderzoek en ontwikkeling geschiedt tegen een achtergrond van moeilijk meetbare, maar toch spectaculaire technologische veranderingen. Ik bedoel daarmee niet de Jules Verne-achtige ontwikkelingen zoals de maanlanding, het door genetische manipulatie kruisen van een geit met een schaap, of het vervaardigen van een kunsthart. Ik bedoel spectaculair in de kwaliteit en de lage kosten van de produkten die ons dagelijks omringen en in de aard van het produktieproces, in industrie, landbouw of dienstensector, waarin deze gefabriceerd worden.

Al tientallen jaren achtereen dalen computerkosten met 30 procent per jaar. Sinds het begin van de jaren zeventig is in de produktie van kleuren televisietoestellen in Europa de bewerkingstijd in de montage teruggelopen van tien naar anderhalf uur. Tegelijk liep het aantal onderdelen van een toestel terug van 450 naar minder dan 200 (Bolwijn et al., 1986; blz. 312). In een typische fabriek ir de elektrotechnische industrie verminderde in diezelfde 15 jaar de doorlooptijd van 46 weken tot minder dan 1 week. Voorraden verminderden van 5 maander naar 1 maand, uitval van 25-30 procent naar 9 procent.

De feitelijke technologische verandering van de laatste jaren is niet alleen spectaculair, maar ook van een andere aard dan in het verleden. Er valt onderscheid te maken tussen soorten technische veranderingen op basis van waar de voornaamste obstakells tegen voortgang liggen: in de research, bij lhet ontwerp of in de applicatie. Voorbeelden van een technologie waarvoor research cruciaal is zijn bio-technologie en de geneesmiddelenproduktie. Als eenmaal de doorbraak in de research heeft plaatsgevonden verloopt de gang naar de markt tamelijk rechtlijnig. Gespecialiseerde onderzoekers en goed uitgeruste laboratoria zijn bepalend voor het succes van het innovatie proces. Daarentegen zijn ontwerp en produktontwikkeling cruciaal in technologische gebieden zoals transportmiddelen en computer hardware. De natuurwetenschappelijke kennis op deze gebieden is of tamelijk stabiel of, indien in snelle ontwikkeling, beschikbaar aan meerdere concurrenten. Sukses is afhankelijk van het oplossen van technische ontwerpproblemen, meestal met bijdragen uit meerdere disciplines. Standaarden en dominante ontwerpen zijn belangrijke instrumenten van verandering.

Een derde soort technologische verandering wordt vooral bevochten op het punt van de applicatie. De belangrijkste obstakels liggen noch in de research noch in het ontwerp. Vertraging of eenzijdigheid in de toepassing van de technische mogelijkheden liggen in de toepassing ter plekke. De landbouw is traditioneel een gebied waarin technische ontwikkelingen sterk afhankelijk waren van lokale omstandigheden, zoals de aanwezigheid wan proefstations, landbouwconsulenten en het opleidingsniveau van de boeren. Niet alleen obstakels maar ook de sturing van de technische ontwikkeling zijn lokaal. Afhankelijk van de plaatselijke cultuur, machtswerhoudingen of organisatie worden andere toepassingsrichtingen uitgewerkt. De huidige ontwikkelingen op het gebred van fabrieksautomatisering en zelfs het gehele gebied wan de informatie technologie lijken eveneens sterk lokaal bepaald te zijn (Prakke, 1986). Zo is het in een recent onderzoek (Schultz-Wild, 1987) aangetoond dat Duitse bedrijwen tot een geheel andere configuratie komen van arbeid en technologie bij de introductie van CNC-draaibanken dan vergeiijkbare bedrijven in Frankrijk, onder andere doon een verschil in opleidingsniveau van de werknemers. Applicatie- technologieëtn 
zijn afhankelijk van stimuleringsinstrumenten zoals demonstratie projecten en de ontwikkeling van nieuwe sociale netwerken, en in mindere mate van R\&D.

Kortom, gebieden van technologische ontwikkelingen kunnen relatief sterk bepaald en gestuurd worden of in de researchfase, of in de ontwerpfase of in de applicatiefase* $)$. Het huidige belang van de informatie technologie, die tot de laatste categorie behoort, betekent dat nu andere innovatie- en diffusiemechanismen kritiek zijn dan, bijwoorbeeld, veertig jaar geleden toen ontwikkelimgen in de petrochemie en in transportmiddelen de boventoon voerden. Een dergelijke conclusie wordt ook getrokken in het technologische verkenningen programma van de Europese Giemeenschappen, FAST. Hier wordt gesproken over de 'user orientation' die van doorslaggewend belang is in de ontwikkelingen op met informatie technologie verbonden gebieden zoals de nieuwe diensten, telecommunicatie en automatisering.

De stijging in de maatschappelijke uitgaven aan onderzoek en ontwikkeling en de vaak - maar niet altijd - spectaculaire resultaten gaan gepaard met een erkenning van technologie als strategische factor, zowel in het bedrijfsleven als bij de overheid. Steeds vaker zie je dat ondernemingen in thun strategie keuzes maken voor bepaalde gebieden van technologische kennis, een "core technology', op basis waarvan gestreefd wordt naar exclusiviteit in de markt. Dit is een belangrijke verschuiving ten opzichte wan tien jaar geleden en daarvoor, toen het heersende strategische denken gericht was op doelen zoals synergie, schaalvergroting, verticale integratie, beheersing van grondstoffen, door regulering beschermde markten, lage loonkosten of marketing. De opkomst van technologiestrategieen is meer dan een modieus verschijnsel. Het is een afspiegeling van de reële situatie op de huidige mondiale markten. Het vinden van objectieve maatstaven is bij een dergelijk verschijnsel een probleem. Opmerkelijk is echter de groei van het aantal adwiseurs bij bureaus zoals Arthur D. Little, SRI, Booz- Allen en Arthur Anderson dat zich bezighoudt met "technology" consulting'.

De meest sprekende case op dit gebied is de Amerikaanse industrie voor consumentenelektronica. In de jaren zeventig volgden bedrijven als RCA en General Electric de kostenstrategie van het goedkoop inkopen van Japanse elektronische componenten. Te laat kwam men tot het inzicht dat het kunnen produceren van deze componenten juist de 'core technology' vormde van de ondernemingen. Door elders in te kopen werd deze uit handen gegeven, aan de Japanse concurenten, wardoor er nu geen grote Amerikaanse producenten van consumentenelektronica meer bestaan.

Als we nu kijken naar de benadering van het strategie-vraagstuk van de internationaal toonaangevende adviesbureaus, dan zien we dat er gedacht wordt in

*) Wie geinteresseerd is in detail kennis te nemen van het proces van technologische ontwikkelingen als mensenwerk wordt voor een reseach-technologie verwezen naar Watson's (1968) The double helix, voor cen on rwerp-technologie naar Kidder's (1981) The soul of a new machine, en voor een applicatie-technologie naar de debatten wan de Tweede Kamer met Deetman over de automatisering van het systeem van studie-financiering. 
termen van combineren wan produkt, markt en technologie. Technologie wordt echter in deze nieuwe benadering nier langer eng opgevat als schaalvergroting, technische kennis of produktinnovatie, maar als produktiefactor op basis waarvan naar exclusiviteit in de markt wordt gestreefd.

De benadering van het adviesbureau $A D L$ is in dit verband illustratief. Het uitgangspunt is een typologie van technologieën van belang voor de onderneming. Gesproken wordt over:

- 'key technologies, which determine the competitive position with regard to both products and processes';

- 'basic technologies, which are easy to acquire and therefore do not determine a differential competitive position';

- 'emergent technologies, which are capable of modifying the future bases of competition but are still at the experimental stage'.

Duidelijk is dat deze typologie niet alleen berust op intrinsieke eigenschappen van de technologieën maar vooral ook de nadruk legt op hun marktaspecten, oftewel de mate waarin exclusiviteit ter versterking van de concurrentiekracht erdoor kan worden bereikt. De concurrentiekracht wan een bedrijf is afhankelijk van de positie ten aanzien van 'key technologies' en van 'emergent technologies". Indien het bedrijf ten aanzien wan beide sterk staat, is een offensieve strategie mogelijk.

De overschakeling bij Akzo van bulkprodukten, met name synthetische vezels, naar chemische specialiteiten is een voorbeeld van een strategie gericht op exclusiviteit door middel van technologie. Dit gebeurt niet door middel van $R \& D$ maar door overnames.

Het zich verzekeren vam exclusiviteit op korte en lange termijn op basis van een bepaalde positie in een technologie is een complexer probleem dan produktontwikkeling of het traditionele portfolio- management. Van belang hierbij is de aanpassing van thet bedrijf aan de dynamiek in de technologie. Dit is technologie management in de breedste zin:

- leercurve-effecten moeten worden uitgebuit;

- er moet een dynamisch evenwicht tussen de verschillende leercurven (diversiteit in ontwikkelingssnelheid en technologische basis) in de portefeuille van de onderneming worden gehandhaafd;

- vroegtijd moeten nieuwe leercurven, met een potentieel voor exclusiviteit, ontdekt en in eigendom worden verkregen.

De overheid in zijn diverse gedaantes is zich de laatste tien jaar ook in toenemende mate met technologie gaan bezighouden. Technologie in de vorm van tech. nische wernieuwing wordt gezien als een belangrijk middel om de economische stagnatie te doorbreken "zowel op nationaal als op Europees niveau. Het technologiebeleid van de overheid, nauw verwant aan het bij economen vertrouwdle industriebeleid, lijkt bij uitstek geschikt toepassingsgebied van economische inzichten. Maar Heertje (1973; blz. 320) heeft het reeds gezegd: ten onrechte laten we de technische ontwikkeling over aan God en de ingenieurs. Bij veel technologieprogramma's van de overheid ontbreekt echter zowel de goddelijke als de onzichtbare hand. Daar hebben de economen zelf schuld aan. Het empirisch onderzoek en het statistische apparaat op het gebied van technische ont- 
wikkeling dient sterk verbeterd te worden. Van een goed gefundeerde economische evaluatie van technologiestimulering is zelden sprake. Meer economen dienen een realistische, op praktijkkennis gebaseerde kijk te verkrijgen op het proces wan technische ontwikkeling. Die kan alleen verkregen worden door nauwe betrok kenheid met de praktijk van de huidige technologie. Dan blijkt het vaak mogelijk om tot kwantificering te komen van aanvankelijk ondoorzichtige en gemystificeerde ontwikkelingen. $K$ wantificering is een van de eerste taken wan de econoom. Hoewel de tekenen kunnen bedriegen, is gebrek aan ieder teken de grootste uitnodiging tot gebrekkige besluitworming over schaarse middelen. Door nawwe betrokkenheid wordt ook bevorderd dat de juiste vragen worden gesteld en dat de econoom met zijn eigen invalshoek door de ingenieur, wan nature hoofdrolspeler op dit gebied, als gelijkwaardige partner wordt aanvaard.

Een goed voorbeeld is het vraagstuk van de overheidssubsidie aan technische vernieuwing in de industrie, het vraagstuk waarop technologie stimuleringsprogramma"s een antwoord proberen te geven. Waar het om gaat is dat er een aansluiting wordt gevonden tussen de mogelijkheden en beperkingen van het besluitwormingsproces van de overheid met het door kenmerkende onzekerheden bepaalde beslluitvormingsproces ten aanzien van innovatie in bedrijven. Stimuleren tot technische vernieuwing is een wezenlijk complexere opgave dan stimulering tot investeringen. Bij stimulering van technische vernieuwing moet rekening worden gehouden met de verschillende fasen in het innovatieproces (schema 1), van fase 1, het vaststellen dat technisch onderzoek en ontwikkeling überhaupt nodig is voor het bedrijf, tot fase 7 , het besluit een gepreciseerd nieuw produkt of proces met volledige technische specificaties te gaan produceren. Naarmate de specificatiegraad toeneemt verandert de aard van het besluitvormingsproces. De benodigde infomatie verandert van publiek en algemeen naar privaat en specifiek. De mogelijke rol van de overheid of een van haar organen, hoezeer ook op armslengte geplaatst, verandert en wordt beperkter als de markt in zicht komt. Economen zouden bij de conceptie, uitvoering en evaluatie van dit soort beleid een grotere rol kunnen spelen dan nu het geval is. 


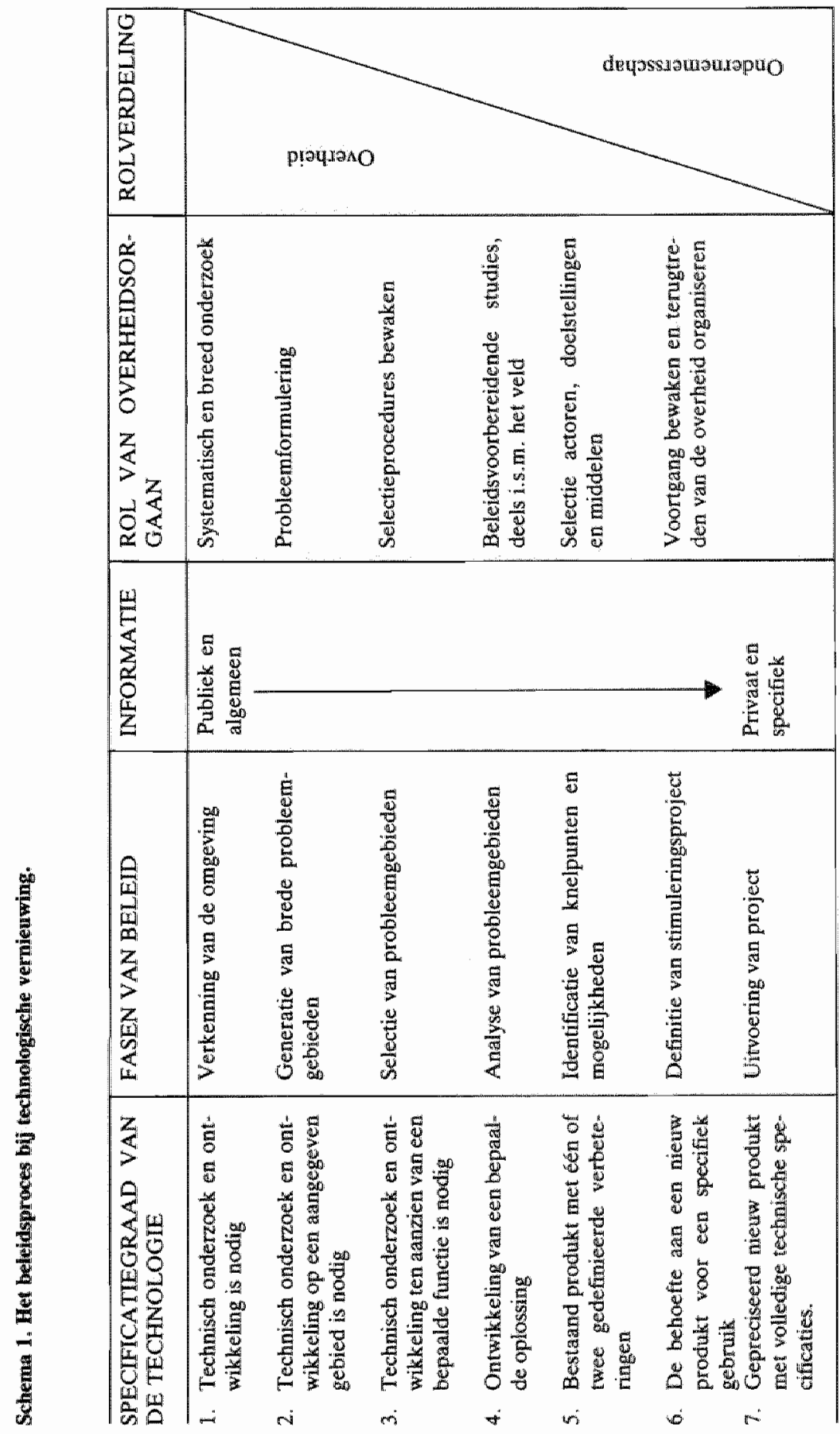


Een tweede manier om technologie te benaderen is als algemeen metafoor voor veranderingsprocessen waarmee de econoom te maken krijgt. Technologie in deze zin nodigt uit tot het bestuderen van de veranderingen die in het economisch bestel platatsvinden en - logische consequentie voor een gammawetenschap - uiteindelijk tot de beinvloeding van die verandering.

Op theoretisch gebied is voor economen als Nelson, Freeman en Soete, om maar niet al te ver van huis te beginnen, technologie de aanleiding geweest, ook in hun eigen individuele intellectuele geschiedenis, om als tegenhanger van de traditionele, statische evenwichtsanalyse op zoek te gaan naar een evolutionaire theorie. Het Studiecentrum Technologie en Beleid van TNO voert studies uit op zeer diverse beleidsgebieden, waarbij uiteindelijk vaak niet de technologie maar de ontwikkelingen in het beleid centraal komen te staan. In allerlei wetenschappen zie je een verschuiwing wan de belangstelling van statische benaderingen zoals ex post analyse, indelen en normontwikkeling naar een belangstelling voor veranderingsprocessen. In de psychologie: minder persoonlijkheidskenmerken en meer persooniljke groei. In de organisatietheorie: minder aandacht voor de optimale 'span of control' en meer 'organizational learning'. In de juridische wetenschappen, als ik de oratie van Roos (1987) goed heb begrepen, minder aandacht voor de optimale codificatie, e.g. het Nieuw Burgerlijk Wetboek, en meer alandacht voor de ontwikkelingen in de casuistiek. In de opleiding tot scheikundig ingenieur aan de T.U. Delft heeft het vak chemische analyse ruimte moeten maken voor procestechniek.

Het belang van technologie in deze zin voor economen is dat het een verandering in de omgeving van het te bestuderen economische systeem vertegenwoordigt die dwingt de aandacht te richten op de veranderingsprocessen binnen dat systeem. Door die veranderingen leren we het systeem kennen. Technologie is niet de enige veranderingsfactor, maar momenteel wel een zeer belangrijke, of we nu naar de internationale handel kijken, naar de kredietverlening aan entrepreneurs, naar de organisatie van onze fabrieken en kantoren, of naar lange termijn ontwikkelingen. Het onderzoek in de internationale handel met een oog voor technische ontwikkelingen richt zich dan niet in de eerste plaats op de statische comparatieve voordelen van Europa in relatie tot de V.S. of Japan, maar op het effect van de ontwikkelingen in de informatietechnologie op de concurrentiekracht van Europa.

Een ander onderwerp dat het verdient dynamisch, in de context van de huidige technische ontwikkeling bekeken te worclen is kapitaalallocatie, het mechanisme van kredietverlening aan het bedrijfsleven. Zonder technische ontwikkeling valt dit mechanisme in enkele zinnen uiteen te zetten (zie ook Heertje, 1986). Als de bestaande produktiemiddelen versleten zijn, worden ze door nieuwe, identieke vervangen. De allocatie van produkten en produktiemiddelen, waaronder kapitaal, wordt tot stand gebracht door het prijsmechanisme. Marktgebreken worden gecorrigeerd door ingrijpen wan de overheid. Door de aanname wan volkomen kennis is er geen verschil tussen ondernemers en ambtenaren wat betreft de kwaliteit van het afwegingsproces. In deze wereld zonder technische ontwikkeling mar met volkomen kennis, zekerheid en hoogstens tijdelijke 
inefficiency is de neo-klassieke evenwichtstheorie van toepassing.

De econoom die zich laat inspireren door hedendagge innovatieprocessen ziet echter nieuwe vormen van kapitaalbehoefte ontstaan. Vergeleken met twintig jaar geleden is de technologie kleinschaliger geworden. In de chemische industrie zien we minder schaalvergroting en meer specialiteiten. In de micro-elek * tronica minder grote computers en meer mini-computers en software. We zien minder staal en meer 'nieuwe materialen', minder kemenergie en meer energiebesparingsapparatuur. In de bio-technologie lopen onafhankelijke nieuwe bedrijfjes vaak voorop. Dit zijn niet directe gevolgen van een maatschappelijke voorkeur voor kleinschaligheid maar van de veranderende aard van de dominante technologieën. We zien het verschijnsel van de succeswolle allocatie van kapitaal aan zeer jonge bedrijfjes met nieuwe, eigen produkten in New England en in Silicon Valley, het inmiddels veelbejubelde "venture capital". Heertje noemt een aantal veranderingen in de aannames wanneer in de economische analyse technische verandering toegestaan wordt. Kennis over nieuwe technieken wordt dan ontwikkeld en toegepast in nieuwe produkten en produktiemethoden. De voorkeuren van de consumenten veranderen door de nieuwe produkten. Produktietechnieken veranderen voortdurend. De technische ontwikkelingen zijn veelal niet omkeerbaar en niet deelbaar, gaan gepaard met uiteenlopende schaal- en externe effecten. De markt is dan een ont dekkingsmechanisme van nieuwe behoeften, produktiemethoden en produkten. Schumpeteriaanse concurrentie treedt op tussen entrepreneurs die investeren op grond van onvolkomen kenmis. Onzekerheid voert de boventoon. Dit soort concurrentie, waarin de enige zekerheid is dat gebrek aan risico nemen tot ondergang van het bedrijf leidt, wordt door Burton Klein (1979; blz. 71) omschreven als "the economics of the hidden foot".

Deze dynamische allocatie van kapitaal onderscheidt zich van de statische, die gericht is op het voorzien in gegeven behoeften. De kwaliteit van het allocatiemechanisme betreft nu de efficiency van het ontdekkingsproces, het ontwikkelen van rieuwe routines. De technische ontwikkeling is een voortdurende bron van dynamische $X$-inefficiency. De vraag van de econoom die een nadere analyse van het proces van kapitaalallocatie wil maken (Prakke, 1988) wordt dan: in welke mate draagt de huidige institutionele vormgeving van 'venture capital" in Nederland (of Europa) bij aan de vemindering van de dynamische $X$-inefficiency? De daaruit voortwloeiende vragen zijn of her anbod van risico kapitaal ten bate van technische innovatie, zowel op de kapitaalmarkt als birmen grote ondernemingen voldoende is. Daarbij kumnen hoeveelheid, structuur en kwaliteit onderscheiden worden. Leidt de ondernemingsstrategie van grote ondememingen in Europa tot voldoende allocatie van kapitaal an de irnovatieve bedrijfsonderdelen (business units)? Zijn de kapitaalmarkten instaat kapitad over te brengen naar economische sectoren met een groeipotentieel en waar het ontdekkingsproces relatief kansrijk is? In welke mate verschillen markten en hièrarchieen in de kwaliteit van hum mechanismes voor allocatie van kaputaal voor proces- en voor produktimnovatie? Dit soort wragen dwingen de econoom tot het zich eigen maken van aanzitrilijk inzicht in de aard van de diverse innovatieprocessen en institutionele randvoorwaarden. Er moet gebruik gemaakt worden van zowel bedrijfs-economische alls algemeen economische in- 
zichten. De technologie die door zijn maatschappelijk belang de aanzet geeft tot dit soort onderzoek dwingt niet alleen tot een veranderingsperspectief maar ook tot multidisciplinariteit.

Vanuit een orientatie op veranderingsprocessen kijken we op het gebied van de automatisering van kantoren en fabrieken niet naar de optimale configuratie van taken van mensen en van machines, maar naar de aanpassingsprocessen die zich ten gevolge valn automatiseringsmogelijkheden voordoen. De concrete technologische verandering wordt dan als 'tracer' gebruikt: het systeem-vreemde element dat wordt ingevoerd en door de onderzoeker van moment tot moment gevolgd. De tracer kan een CNC draaibank of een beeldscherm zijn. Steeds gaat het erom te ontdekken hoe de organisatie reageert, evenzo bij een tracer studie in de geneeskunde het doel is te leren hoe het lichaam op een bepaalde, van buitenaf geïntroduceerde stof (die "tracer") reageert. Aldus leren we het systeem beter kennen, of het nu een menselijk lichaam is of fabriek die een robot invoert (Prakke, 1987). Op het gebied van automatisering wordt overigens nogal eens opgemerkt dat economen niet bruikbaar zijn omdat ze alleen tot boekhouden in staat zijn. De complexiteit wan een automatiseringsproces, met vele moeilijk vooraf te $k$ wantificeren kosten en baten zou daarom buiten de competentie van een econoom liggen. Laten we er voor zorgen dat dit van de toekomstige Maastrichtse economen niet gezegd zal worden.

Langere termijn technologische veranderingsprocessen ontwikkelingen, zeg maar macro-technologie, zoals de informatisering van produktieprocessen, biotechnologie, telematica, optomatronica en de ontwikkelingen op het gebied van nieuwe materialen dwingen de econoom tot het ontwikkelen van een visie op het economische systeem op lange termijn. Jammer genoeg is de inbreng van economen op dit gebied van lange termijn technologische werkenningen, althans in Nederland, tamelijk gering. In dit verband heb ik vaak moeten aanhoren dat economen voor dit werk niet goed bruikbaar zijn omdat ze in hun disciplinaire vorming alleen hebben geleerd

om achteruit te kijken. Laten we er voor zorgen dat dit van de Maastrichtse economen niet gezegd zal worden. Alleen dat al is een goede reden om technologie een belangrijke plaats in te laten nemen in ons onderzoek en onderwijs.

De gebrekkige inbreng van economen in lange termijn toekomstverkenningen betekent miet dat de discipline op dit gebied niets zou kunnen bijdragen. Veel te gemakkellijk wordt deze hele discussie overgelaten aan technologen. Dat is slechts ten dele terecht. Zij hebben, in tegenstelling tot economen een ontwerpgericht denken meegekregen. Niet problemen worden naar voren gehaald, maar mogelijkheden. Economen zijn echter veel meer toegespitst op het onderkennen van indirecte effecten, afwentelingsmechanismen, wisselwerking tussen vraag en aanbod en de wonderen van het prijsmechanisme. Tenslotte is een van de weinig zekerheden op lange termijn dat er vraag en aanbod zal zijn. Een van de grote manco's van de door de Club van Rome aangezwengelde discussie over de 'Grenzen van de Groei' in de jaren zeventig was dat er nauwelijks economen aan deelnamen. Deze hadden kunnen opmerken dat op de middellange termijn het prijsmechanisme een vaak werkbare oplossing van schaarsteproblemen mogelijk maakt. De huidige overproduktie en daardoor het lage prijsniveau van 
bijna alle belangrijke grondstoffen, zelfs van ruwe olie, is daarvan een treffende illustratie.

\section{ONTWERPGERICHTHEID}

Een door de technologie geïnspireerde oriëntatie op veranderingsprocessen in het economische stelsel kan vervolgens leiden tot de behoefte een actieve rol te spelen bij die veranderingen. Juist op dit punt loont het onderscheid te maken tussen de economie en de economen. Slechts bij uitzondering bevindt eern wetenschap, en zeker de economische, zich in de positie eenduidig en zelfbewust veranderingsprocessen te kunnen beinvloeden. Voor de individuele afgestudeerde econoom is beïnvloeding bijna altijd een doelstelling, of hij nu aan de universiteit werkzaam is, beleidsambtenaar is op een ministerie of produktmanager bij een levensmiddelenconcern. Dit gegeven vormt een belangrijke uitdaging aan zowel onze theoretische ontwikkeling als aan de vormgeving van ons onderwijs aan studenten. Beïnvloeding van het economische stelsel door theorievorming is uiteraard niets nieuws. Veel zo niet al het vooraanstaande theoretische werk van de afgelopen twee eeuwen is tot stand gekomen vanuit de behoefte radicale veranderingen in beleid tot stand te brengen. Adam Smith in zijn strijd tegen het mercantilisme, Riccardo tegen de 'corn laws" Marx tegen de uitbuiting van de arbeiders en Keynes voor een actieve bestrijding van de werkloosheid.

Anno 1988 lijkt het echter dat de richting van de veranderingen in het economisch systeem slechts in zeer geringe mate beïnvloed wordt door nieuwe inzichten uit de economische wetenschap. De meest radicale beleidsinterventies, zoals in de V.S. en het V.K. zijn genomen op initiatief van niet-economen en zelf over lange perioden in strijd met de heersende inzichten van het economische wetenschappelijke establishment. Moeten we ons niet afvragen of het niet erg lang heeft geduurd voordat de belastingverlagingen van Reagan en Thatcher gevolgd zijn door een groeiende wetenschappelijke belangstelling voor 'rational expectations' en erkenning van een mogelijk positief verband tussen belastingverlaging en belastingopbrengsten voor hoge inkomensgroepen. Ook het technologiebeleid, als Nederlandse versie van aanbodseconomische denkbeelden, is slechts in zeer geringe mate het geesteskind van vakeconomen. Vooral ingenieurs en ondernemers hebben die discussie gevoerd. Al meer dan tien jaam vervullen niet economen maar wis- en natuurkundigen de functie van minister van Economische Zaken. De economische theorie dreigt zich af te zonderen in een ivoren toren. Enkele jaren geleden klaagde Leontief, Nobelprijswinnaar in 1973, in een brief aan het tijdschrift 'Science':

"Page after page of professional economic journals are filled with mathematical formulas leading the reader from sets of more or less plausible, but entirely arbitrary, assumptions to precisely stated but irrelevant conclusions".

Leontief had een analyse gemaakt van artikelen in de American Economic Review tussen 1972 en 1981 waaruit bleek dat meer dan de helft bestond uit mathematische modellen zonder empirische gegevens. Minder dan 1,4 procent 
van alle artikelen bevatte gegevens verzameld door de auteur (bron: Economist, 22-11-1984).

Een interessant aspect van de door techmische ontwikkelingen geïnspireerde economische analyse van de afgelopen jaren is dat duidelijk gestreefd wordt uit de ivoren toren te breken. Men neigt tot het zoeken naar voor de economie niet traditionele bronnen van gegevens. Zie bijvoorbeeld Klleinknecht (1986) met zijn poging tot een nieuwe, verbeterde meting te komen van $R \& D$-inspanning van kleine bedrijven en Hagedoorn (1988) met zijn empirisch onderzoek in de process control equipment industrie. Bovendien wordt actief gezocht naar een nawwe betrokkenheid bij de vormgeving van beleid, althans wat betreft zulke instellingen als het Engelse Science Policy Research Unit, het TNO Studiecentrum yoor Technologie en Beleid en, vanaf dit jaar, het Maastrichtse MERIT. Ontwerpgerichtheid lijkt wel de gemeenschappelijke noemer van door technologische verandering geïnspireerde economisch onderzoek.

\section{ONDERWUS AAN ECONOMEN}

De volgende uitdaging is om het ontwerp of interventie gerichte denken, waartoe de technologie als metafoor voor veranderingsprocessen ons oproept te vertalen in het onderwijs aan aanstaande economen. Vergeleken met andere economische faculteiten in Nederland heeft Maastricht naar mijn mening een uitstekende uitgangspunt in de keuze woor het systeem van probleemgestuurd onderwijs. Dit nodigt ait tot een actieve betrokkenheid met de economie die via traditionelere vormen van kennisoverdracht waak ontbreekt. Omdat echter het overgrote deel van de afgestudeerde economen niet via de theorievorming maar via de dagelijkse beroepspraktijk zijn invloed witoefent op veranderingen in het economische systeem is het van het grootste belang aandacht te besteden aan het overbrengen van niet alleen kennis maar ook vaardigheden en attitudes. Op dit punt kan de technologie een inspiratiebron zijn omdat de ingenieursopleidingen traditioneel relatief succesvol zijn in het overbrengen van een probleemoplossende, ontwerpgerichte instelling. Op het gevaar af stereotypes te creëren durf ik wel - op basis van vele jaren werken in multidisciplinaire teams - te zeggen, dat in de benadering van complexe problemen economen en andere sociale wetenschappers doorgaans uitblinken in conceptuele kritiek en ingenieurs in het onmiddellijk zoeken naar, ontwerpen van, een beste oplossing. Het zou daarom goed zijn te streven naar een onderwijservaring voor economen waarin een sterk element wan ontwerpgerichtheid is ingebouwd. Dit dient uiteraard niet ten koste te gaan van het aanleren van een kritisch, anallytisch vermogen. Dat is een valkuil waarin al te zeer op de praktijk gerichte business schools dreigen te vallen. Door het al te snel en ondoordacht uit de grond stampen wan nieuwe bestuurs- en bedrijfskundige opleidingen dreigen deze "-kundigen" de "-gogen" wan de jaren negentig te worden.

Donald Schön (1987), evenals Schumpeter en zovele anderen, een uit Centraal Europa stammende Amerikaan, heeft een aantal belangwekkende ideeën over beroepsgericht academisch opleidingen ontwikkeld. Op basis van studies van de opleiding tot musicus, psychiater, architect en organisatie-adwiseur lanceert hij voorstellen over de noodzaak theorie en praktijk in het onderwijs bijeen te 
brengen. Hij pleit woor "the reflective practitioner"in dit soort beroepen, de man of wrouw die in staat is steeds weer de gang te maken var theoretisch inzicht naar praktijkervaring en weer terug. Doordat geen van deze beide aspecten overheerst wordt verstarring bestreden. De "reflective practitioner" kan, in de ogen vam Schön, het produkt zijn wan een gestructureerde onderwijserwaring die hij "the reflective practicum" noemt. Hierin komen student en docent in een bewust ontworpen sociaal psychologisch proces bijeen. Kennis wordt niet bevroren. Het doel is het vermogen tot leren uit de eigen beroepservaring te vergroten. Het lijkt me dat mannen en vrouwen die in staat zijn tot dit soort leren ("double loop learning") belangrijk zo niet onmisbaar zullen zijn voor de door Den Hertog bepleitte lerende organisaties.

Hoe leiden we "reflective practitioners" op in de economie? Schön spreekt niet over economen en deze faculteit is over het onderwerp van probleemgestuurd onderwijs voorlopig nog niet uitgesproken. Wat mij betreft mag er naar inspiratie gezocht worden in de technologie. Vooral in de gedante van uitdagende veranderingsproces en de ontwerpgerichtheid. De term "ontwerpeconoom" is wellicht te modieus. Toch moedigt het aan algemene economen vanaf het begin begrip bij te brengen voor de essentiële veranderingsprocessen in thet economisch systeem en de rol van hun eigen beleidsinterventies daarbij. Bedrijfseconomen zouden invulling kunnen geven aan dit perspectief door practica waarin 'animal spirits' niet allen beschreven worden maar ook geoefend door middel van het experimenteren met ondernemerschap in quasi- realistische eigen bedrijfjes. In de V.S. zijn daar interessante ervaringen mee opgedaan. Gezocht moet worden naar zo realistisch mogelijke "reflective practica". De in het kader van MERIT ontwikkelde voorstellen voor een afstudeervariant "Innovatie Economie' is daartoe een bescheiden aanzet.

\section{Referenties}

Bolwijn, P.T., Boersma, J., Breukelen, Q.H. van, Brinkman, S en Kumpe, T. Flexible Manufacturing, Elsevier Science Publishers, 1986.

Fischer, E.J. Geschiedenis van de techniek. Martinus Nijhoff, 1980.

Hagedoorn, J., Kalff, P. en Korpel, J. Technological development as an evolutionary process, Elsevier Science Publishers, 1988.

Heartje, A. Economia en technische ontwikkeling, Stenferi Kroese, 1973.

Heertje, A. "Hoofdlijnen van een integral technologiebeleid", ESB, 9-7.1986

Kidder, T. The soul of a new machine, Little, Brown, 1981.

Klein, B.H. "The slowdown in productivity advances: a dynamic explanation", in Hill, C.T. en Utterback, J.M. (red.), Technological inhovation for a dynamic economy. Pergamon Press, 1979.

Kleinknecht, A. Indiustriele innovatie in Nederland, Van Gorcum, 1987.

Prakke, F. "Manufacturing innovation between the state and the market", in Gerstenfeld, A., Bullinger, H.J. en Warnecke, H.J. (red.), Monufacturing research: arganizanonal and institutional issues. Elsevier Science Publishers, 1986.

Prakke, F. (red) "Human factors in system design: methodology and cases in factory automation". Rapport aan DG-V, EG; STB-TNO, Apeldoorn, 1987.

Prakke, F. "The financing of innovation", in Heertje, A. (ed.) Technical Change and Financial Innowation. To be published by Basil Blackwell in 1988. 
Roos, N.H.M. De Nederlandse priwatrechuleer in dramatisch perspectief. WoltersNoordhofi. 1987.

Schmookler, II. 'Technological change and economic theary'. AER, 1965, blz. 335 .

Schorn, D. Educating the reflective practitionter; toward a new design for teaching and learning in the professions. Jossey. Bass, 1987.

Schultz-WUld, R. "Transformation Conditions for Future Factory Stnuctures: Technology, Organization, Education and Wocational Training, options for "hew production systems" FAST paper, EC Brussels, 1987.

Soete, L. L.G. Technologie en economie, Oratie, Faculteit der Economische Wetenschappen, Rijksuniversiteil Limburg, 1987.

Watson, J.D. The dowble helix, apersonal account of the discovery of the structure of DNA, Penguin, 1970 . 